\title{
Editorial
}

\section{Sustainable Landscape Management and Planning}

\section{Ivo Machar}

Department of Development and Environmental Studies, Faculty of Science, Palacky University Olomouc, 77146 Olomouc, Czech Republic; ivo.machar@upol.cz

Received: 11 March 2020; Accepted: 12 March 2020; Published: 18 March 2020

\begin{abstract}
Dynamic changes of landscape structure affect the abundance and distribution of organisms. Currently, changing land-use is one of the major forces altering ecosystem services in landscapes globally. Human activities are transforming land at a faster rate and greater extent than at any time in history. This is a perspective challenge for research in the field of emerging sustainability science. The human conversion of natural habitats and land use change is not only a local/regional phenomenon but can be considered as one of important global change drivers. Some of the impacts of global change on biodiversity can be studied only at the landscape scale, such as the climate change-induced shift of vegetation zones. A landscape perspective fosters a multi-scale approach to sustainable landscape management and landscape planning. Additionally, a landscape scale is very useful for the innovative application of the common management paradigm to multiple uses in agriculture, forestry and water resource management. The need for sustainable landscape management and planning is now obvious. Landscape conservation seems to be a new paradigm for the conservation of biodiversity. This Special Issue (SI) of the Sustainability journal is focused on building a bridge between scientific theory and the practice of landscape management and planning based on the application of sustainability as a key conceptual framework. Papers dealing with various theoretical studies and case studies of the best practice for sustainable landscape management and planning across diverse landscapes around the world are included.
\end{abstract}

Keywords: decision support tools; ecosystem services in landscape perspective; land-use changes; multi-disciplinary approach to landscape research; sustainable agriculture practice; sustainable forest management; sustainable landscape management

Landscapes over the world are diverse and play a crucial role in our lives. Historical land-use changes have significantly affected the abundance and distribution of biota on the landscape scale [1]. Currently, changing landscape patterns and processes in connection with global climate change are one of the major forces altering ecosystem services over the world [2]. Human activities are transforming land at a faster rate and greater extent than at any time in history; for example, the global network of protected areas faces strong human impacts [3], which are reflected at the regional scale in the decrease of the effectiveness iof conservation efforts aimed at the maintenance of natural habitats [4].

Thus, sustainable landscape management and planning is a perspective challenge for research in the field of emerging sustainability science. The human conversion of natural habitats and land use change is not only a local/regional phenomenon but can be considered as one of the important drivers of global change. Some of the impacts of global change on biodiversity can be studied only at the landscape scale, such as the climate change-induced shift of vegetation zones [5]. A landscape perspective fosters a multi-scale approach to adaptive landscape management and landscape/conservation planning [6]. Additionally, a landscape scale is very useful for the innovative application of a common management paradigm for multiple uses in agriculture, forestry and water resource management. Landscape conservation seems also to be a new paradigm for conservation biodiversity. The need for sustainable landscape management and planning is now obvious. 
This Special Issue (SI) of the Sustainability journal is focused on building a bridge between scientific theory and the practice of landscape management and planning based on the application of sustainability as a key conceptual framework. The SI synthesizes our understanding of the sustainability of landscapes with papers dealing with various theoretical studies, and case studies of the best practice of sustainable landscape management and planning across diverse landscapes around the world.

An interesting economical study from China [7] indicated the impacts of both local tax revenue and a fiscal self-financing rate to bridge the gap between land urbanization and population urbanization. These results explained why local government bodies in China choose land urbanization rather than population urbanization from the perspective of fiscal incentives. Human activities in landscapes modify many types of landforms, playing an important role in sustainable landscape management. In [8], the authors focused on anthropogenic landforms and revealed the role of geomorphological heritage in urban landscape for tourism development. Attractive geological landforms such as the karst phenomenon are preferred by visitors to protected landscape areas and are the focus of geology heritage conservation at the landscape scale [9]. Human mining activities have influenced large areas of cultural landscapes, but the impacts of mining on the landscape structure are even more significant in developing countries. As some authors have highlighted in this SI, artisanal and small-scale mining in particular could initiate new geomorphological processes or modify naturally occurring geomorphological phenomena. These dynamic landscape processes are locally constrained by the topography, soil properties, and rock composition. Anthropogenic activities usually lead to the faster degradation or abrasion of soils. This is a reason for the increasing need for a better understanding of the environmental consequences of mining activities in landscapes. Lands directly influenced by mining and post-mining have risen to prominence in the field of restoration ecology. In [10], the authors presented a case study of good practice in the restoration of land degraded by sand and gravel-pit excavation in a cultural landscape in the Central Europe region. The financial costs of the restoration of the landscape for three individual study sites were compared with the monetary assessment of habitats based on special expert methods [11]. The results surprisingly showed that the restoration of natural habitats after mining will establish new natural habitats with a higher monetary value of biodiversity than before mining. This emphasized the key role of best practice in sustainable landscape management.

In Europe, a broad variety of agricultural landscape types have been created by traditional regional farming activities for centuries. However, the fast socio-economic changes during the 20th century have caused the loss of the traditional rural way of life in many regions. The loss of traditional agricultural landscapes across Europe (in accordance with the increasing intensification of agricultural management) is a reason for the decrease in biodiversity at the landscape level. Traditional European agriculture landscape types were studied, and best examples of sustainable agriculture management practice were presented in the literature. However, case studies from the SI indicated the positive external effects of farms on maintaining traditional agriculture landscapes. Landscape management of agricultural land requires an integrated approach, based on the integration of ecological knowledge to landscape management under the practice of landscape planning. An important benefit for landscape planning is also provided by land consolidation projects, which can be widely applied as a methodological approach to the assessment of agricultural land.

Former military training areas in Central and Eastern Europe are unique examples of ecological transition from open agricultural land to forested landscapes with a gradually closing tree canopy. The natural succession of forest communities on abandoned agricultural land is very often limited by strong browsing pressure from large herbivores. The authors of some papers in this SI found that the tree seedlings are protected from browsing by large herbivores by thorny shrubs, which have been established in abandoned open landscapes during the initial phases of forest succession. However, the protection effect of thorny shrubs on the tree seedlings varied among different shrub species. These results suggested an explanation for the regeneration of deciduous tree species under large herbivore pressure. These results can be applied to landscape planning and management in temperate 
forested landscapes, where high densities of large herbivores usually occur without the presence of large carnivores. Similarly, unsuitable overgrazing by domestic livestock has been identified as one of the most important threats to the endemic and endangered population of Dracaena cinnabari in a case study in this SI from Socotra Island (Yemen). Community forestry controlled by a local certification system is suggested as a sustainable land management approach, providing traditional and new benefits and enabling the reforestation of endemic tree species on Socotra Island.

Some papers in the SI were focused on the sustainable management of forested landscapes in a temperate climate zone. The forest heterogeneity has been defined as the main driver providing the large-scale habitat mosaic conditions suitable for a rich diversity of nesting bird species with different ecological niches in temperate floodplain forest ecosystems. Bird diversity is an important indicator of the ecological integrity of temperate deciduous forest ecosystems, and it can be used as a decision support tool for sustainable landscape management strategies in forested landscapes. A very useful tool for landscape analyses and in management strategies is the application of remote sensing methods. The authors of some studies in this SI investigated landcover maps using satellite images for different time spans in order to assess the forest management and deforestation rate in Africa (Angola). Based on definition management zones, the authors of this study developed an original height-diameter model for forest cover as a fundamental support tool in forest planning practice. Similarly, the authors of other studies in the SI used remote sensing data (analyzed by GIS methods) to assess the monetary value of forest biodiversity and ecosystem service capacity. The forest practice can enhance the scenery value of mountain forested landscapes; thus, the estimation of spatial esthetic analyses seems to be a potentially important support decision tool for forest management at the landscape scale. Additionally, the non-production functions of forests can be successfully enhanced by two special global tools for sustainable forest management and conservation: the program of the Forest Stewardship Council and the Program for the Endorsement of Forest Certification.

\section{References}

1. Simon, J.; Machar, I.; Bucek, A. Linking the historical research with the growth simulation model of hardwood floodplain forests. Pol. J. Ecol. 2014, 62, 273-288. [CrossRef]

2. Machar, I.; Vozenilek, V.; Simon, J.; Pechanec, V.; Brus, J.; Fulnecek, P.; Vitek, T. Joining of the historical research and future prediction as a support tool for the assessment of management strategy for European beech-dominated forests in protected areas. Nat. Conserv. Bulg. 2017, 22, 51-78. [CrossRef]

3. Oprsal, Z.; Harmacek, J.; Pavlik, P.; Machar, I. What factors can influence the expansion of protected areas around the world in the context of international environmental and development goals? Probl. Ekorozw. 2018, 13, 145-157.

4. Pechanec, V.; Machar, I.; Pohanka, T.; Oprsal, Z.; Petrovic, F.; Svajda, J.; Salek, L.; Chobot, K. Effectiveness of Natura 2000 system for habitat types protection: A case study from the Czech Republic. Nat. Conserv. Bulg. 2018, 24, 21-41. [CrossRef]

5. Machar, I.; Vozenilek, V.; Kirchner, K.; Vlckova, V.; Bucek, A. Biogeographic model of climate conditions for vegetation zones in Czechia. Geografie 2017, 122, 64-82. [CrossRef]

6. Simon, J.; Machar, I.; Brus, J.; Pechanec, V. Combining a growth-simulation model with acoustic-wood tomography as a decision-support tool for adaptive management and conservation of forest ecosystems. Ecol. Inform. 2015, 30, 309-312. [CrossRef]

7. Li, J.; Zhang, W. Fiscal Incentives and sustainable urbanization: Evidence from China. Sustainability 2020, 12, 103. [CrossRef]

8. Kubalikova, L.; Kirchner, K.; Kuda, F.; Machar, I. The role of anthropogenic landforms in sustainable landscape management. Sustainability 2019, 11, 4331. [CrossRef]

9. Fialova, J.; Brezina, D.; Zizlavska, N.; Michal, J.; Machar, I. Assessment of visitor preferences and attendance to singletrails in the moravian karst for the sustainable development proposals. Sustainability 2019, 11, 3560. [CrossRef] 
10. Brus, J.; Deutscher, J.; Bajer, A.; Kupec, P.; Olišarová, L. Monetary assessment of restored habitats as a support tool for sustainable landscape management in lowland cultural landscapes. Sustainability 2020, 12, 1341. [CrossRef]

11. Pechanec, V.; Machar, I.; Sterbova, L.; Prokopova, M.; Kilianova, H.; Chobot, K.; Cudlin, P. Monetary valuation of natural forest habitats in protected areas. Forests 2017, 8, 427. [CrossRef] 